
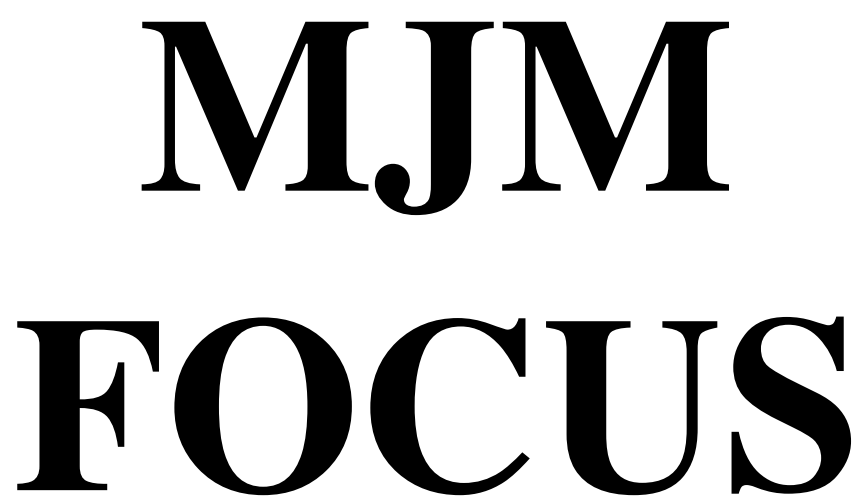

SPECIAL FORUM ON

TRAUMA CARE SYSTEMS

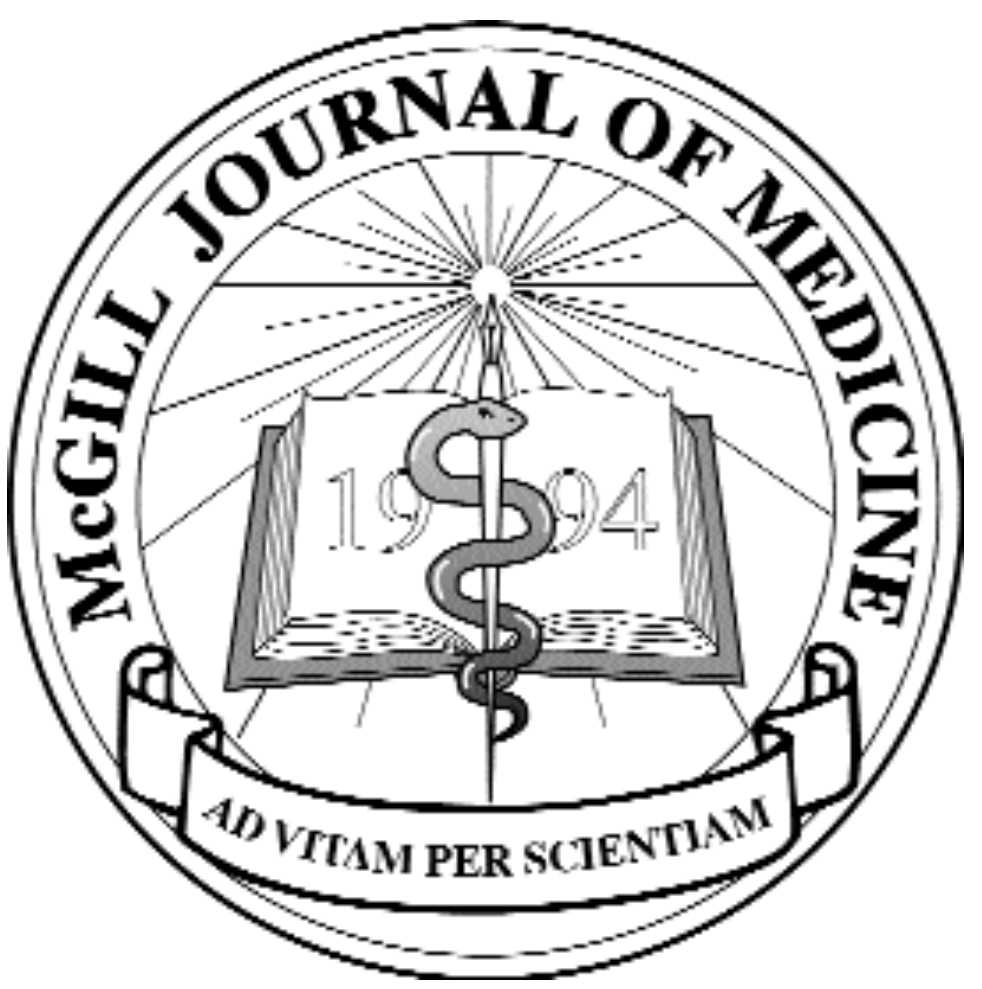

FEATURE REVIEWS

The History of Trauma Care Systems: From Homer to Telemedicine

The Evidence Supporting a Systematic Approach to the Care of the Injured Patient:From Prevention to Rehabilitation

Moishe Liberman, M.D.* ${ }_{\ddagger} \neq$, David S Mulder, M.D.†, John S Sampalis, Ph.D 


\title{
The History of Trauma Care Systems From Homer to Telemedicine
}

\author{
Moishe Liberman, M.D. ${ }^{*} § \S$, David S Mulder, M.D. $\dagger$, John S Sampalis, Ph.D. $\dagger \$$
}

\section{ANCIENT SYSTEMS OF TRAUMA CARE}

The systematic and organized care of injured patients was born in times of war (1). In one of the earliest human writings, Homer in the Iliad, refers to the treatment of the injured patient during the Trojan war (5th century BC) (2). Homer reports a 77\% mortality rate from injury among the 147 wounded soldiers. Surgical care of these injured soldiers was poor compared to the advanced techniques of today. However, the ancient Greeks recognized the importance of systems of trauma care. Injured soldiers were transported to, and treated in, specialized barracks called klisiai or transported to offshore ships for treatment of their wounds.

Hippocrates believed that the care of traumatic injuries during war was the ideal school for surgeons. The earliest documentation of a rudimentary trauma system is the description of medical care for the Roman Legions in approximately 100 AD (3). The Romans had organized on-site first aid, ambulances and surgeons that were on-call 24 hours a day. The trauma care hospitals (valetudinarian) were strategically located near every important encampment and were fairly sophisticated in both design and concept (4).

\section{NAPOLEONIC ERA}

Dominique-Jean Larrey (1766-1842), a Frenchman,

*To whom correspondence should be addressed: Moishe Liberman McGill University Health Centre, Montreal General Hospital Departments of Surgery and Clinical Epidemiology 1650 Cedar Avenue, L10-520 Montreal, Quebec, Canada H3G 1A4 phone: (514) 934-6116, fax: (514) 934-9913 e-mail: moishe.liberman@mail.mcgill.ca

$\dagger$ Montreal General Hospital - Department of Surgery, McGill University Health Center

§Montreal General Hospital - Department of Clinical Epidemiology, McGill University Health Center

$¥$ Hôpital Sacre Coeur - Department of Surgery, Université de Montreal, Montreal, Quebec, Canada was probably the pioneer of systematic trauma care. When international war broke out in 1792 , he became a field doctor in the Rhine army. While waiting in Strasbourg for action, he organized a military medical association. Once the fighting erupted, it did not take him long to realize that an organized system was needed in order to save more soldiers. He wrote (5):

\footnotetext{
"I now discovered the trouble it took us to move our bandaging stations - our military hospitals. According to the rules, they were supposed to stay about five kilometres from the army. The wounded were left on the field until the battle was over, or gathered at some convenient spot to which the ambulance rushed. But the roads were so choked with wagons, and such delays arose, that most of the victims died before the ambulance arrived. This gave me the idea of building an ambulance that was adequate to help the wounded during the actual battle."
}

Following a battle at Limburg in which the conditions were awful and casualties high, Larrey wrote to the General with a proposal; he later wrote of this proposal:

\footnotetext{
My suggestion was accepted and I received orders to construct a cart which I called the flying ambulance. My first plan was to transport the wounded on a horse-litter, but experience soon made me give it up. The next effort was to make a cart with good suspension, combining speed with safety and comfort."
}

Previously, wounded soldiers were left on the battlefield until the fighting ended for the day. Larrey's ambulance could evacuate these soldiers soon after injury. The ambulance carried a doctor, quarter-master, non-commissioned officer, twenty-four infantrymen, and a drummer-boy who carried the bandage kit. He replaced the saddles' pistol holders with courier bags 
full of instruments and bandages. Larrey's "flying ambulance" was a big success. In April of 1973, Larrey was sent back to Paris with orders to arrange flying ambulances for the whole army. For his skill and efforts, Napoleon made him a Baron and the French Army's Surgeon General. Napoleon said of him: "He is the most virtuous man I have ever known."

Military hospitals were designed to concentrate the injured soldiers in one area and operate on them as soon as possible following injury. Larrey realized the importance of the time to definitive care on outcome and arranged to establish his military hospitals as close to the battlefields as possible. Larrey, not only organized to have the wounded evacuated from the battlefield and brought promptly to treatment centers, but was also a pioneer in expanding the role of the military surgeon to encompass all aspects of patient care (6). He was the first to realize the importance of the surgeon in organizing all aspects of the care of the injured patient - the first "trauma system". He worked to improve sanitation, procurement of food and supplies for the sick and wounded, training of medical personnel as well as the rapid evacuation of the wounded from the battlefield.

\section{CIVIL WAR}

The American Civil War was another important step in systematic care of the injured patient. The large number of casualties, primarily due to the advances made in firearms, forced the creation of an extensive infrastructure in order to support the surgeons on the battlefield and care for the injured (1). A major advance in the systematic approach to trauma care came after the war, when the Union published 'The Medical and Surgical History of the War of the Rebellion', in a six volume set (7). This national publication reported the epidemiology of injuries and mortalities that occurred during the rebellion. It also explained the techniques and system elements that were employed throughout the war.

During the war, hospitals were strategically located near creeks in order to provide water that was vital to the care of the injured soldiers. When numerous regimental hospitals were involved in a single battle, they banded together to form a single brigade hospital. The next level of treatment centre was the division hospital and the ultimate level was the general hospital (1). The Union soon recognized the deficiencies in their system of care. The small regimental hospitals were inadequate to care for the wounded. When the regiment displaced, these hospitals could not move with the regiment and transfer all the injured soldiers. This forced the establishment of independent hospitals that could receive the injured soldiers after the regiment relocated. These new hospitals were called "general hospitals", were permanent, and were able to accept the injured from the front line hospitals following displacement of the regiment (1).

\section{WORLD WAR I}

Mechanical advances were responsible for improvements in trauma care in World War I. These advances allowed for field ambulances to become motor driven, instead of horse-driven, as they had been in previous conflicts. Timely evacuation of wounded soldiers occurred through "echelons of treatment facilities" (8). Echelons, each with a greater treatment capacity, were established as a standard protocol. The first tier was the evacuation of injured soldiers from the frontlines by corpsmen and stretcher-bearers. Initial treatments of the wounded men were administered at battle aid stations near the battlefront. At these stations, the injured were administered narcotics, external hemorrhage was controlled and fractures were splinted. Seriously wounded men were then evacuated to clearing stations where surgeons performed emergency surgery, which consisted mostly of the debridement of wounds. Soldiers that survived were then transported to evacuation hospitals located at safe distances from the battlefields. Definitive care was delivered at these centers and patients convalesced with the ultimate goal of returning them to the front lines. This system of escalating echelons of trauma care became the foundation for modern day civilian trauma systems. Due to the huge numbers of casualties seen in some areas, the concept of triage was born. Injured patients were sorted based both on priority and salvageability.

\section{WORLD WAR II}

Emergency medical services in Britain were instituted under the direction of the Minister of Health for both civilian and British Forces in 1940 (9). The British government realised that there would be mass civilian casualties during the war and therefore the War Office and the Minister of Health agreed to pool resources in order to create a system of trauma care that made no distinction between military and civilian casualties. At the outbreak of war it was estimated that approximately 300,000 hospital beds would be needed to treat casualties. Therefore civilian hospitals, civilian physicians and allied health professionals were selected and enrolled into the British Emergency Medical Service. Furthermore, there were specific detailed guidelines established for the organization of trauma centres, their location, corridors for pre-hospital transport and triage, as well as mobile surgical teams which could be deployed close to the areas of casualties. Trauma centres were classified based on resources for 
the first time in history (Adapted from - Bailey H; Surgery of Modern Warfare, 1942, Vol. II p.917(9)):

Class 1A - Hospitals of over 50 beds in which full surgical facilities are available.

Class 1B - Smaller hospitals in which there are good surgical facilities.

Class 2 - Hospitals suitable for the treatment of convalescent surgical and chronic medical cases. In certain cases some of these hospitals were upgraded. Class 3 - Infectious Disease hospitals, which were kept available for their peace-time use.

Special Hospitals - Many well-equipped special hospitals were classified between 1 and 2 . In some cases they were reserved for peace-time use (e.g.: maternity, children's and mental facilities)

In World War II, the immobile medical units that were used in WWI by the United States could not keep up with the fast pace of troop movement. This need gave birth to the "AUX units" which were composed of special surgical teams that travelled to the front lines in order to treat wounded soldiers. Furthermore, the advent of air travel allowed for the evacuation of wounded patients by plane during the WWII conflict, which had not been previously used in war-time situations.

The passage of patients through the echelons of care established in WWI became quicker and more efficient (8). Time lag to definitive treatment was shown to have a negative impact on survival in thoracic and abdominal wounds, as well as in extremity fractures $(10,11)$. Trueta recognized that and wrote: "Surgical aid to casualties in the frontline is impeded by many factors and has to be adapted to varying conditions, but the main basis of success is to have the wounded patient on the operating table at the earliest possible moment" (11). In WWI, the time from injury to definitive care ranged between 12 and 18 hours. This was decreased by $50 \%$ in WWII $(1,12)$. The improvements in time to definitive care as well as the advances in antisepsis, shock resuscitation, transfusion and surgical technique contributed to significantly improved survival rates for injured patients. The many civilian physicians, surgeons and anesthesiologists who were drafted into service in WWII observed the benefits of the systematic approach to trauma care and brought back high expectations to their civilian communities in North America (8).

\section{KOREAN WAR}

The AUX units of WWII were the basis for the establishment of the MASH (Mobile Army Surgical Hospital) units utilized in the Korean conflict. The MASH unit was a mobile surgical hospital comprising 60 beds that operated to the rear of the combat area, just out of range of artillery fire. Injured soldiers no longer had to endure multiple transportations before receiving definitive care. Instead they arrived at definitive care centres often within the "golden hour" of trauma care (13). The introduction of air ambulances and helicopters were also a major advance in the timely care of the wounded in Korea. The Korean War was the first time in military history that the helicopter was used extensively to evacuate casualties from the forward battlefields to supporting medical facilities (14). These transport mechanisms reduced the time from injury to definitive care to between 2 and 4 hours and further reduced mortality to only $2.4 \%(1,4)$.

\section{VIETNAM}

The Vietnam War saw the treatment of 250,000 casualties (15). In Vietnam, due to the mountainous terrain and the consequent difficulty in evacuating injured soldiers, the helicopter was utilized extensively as a part of the pre-hospital arsenal $(16,17)$. The first helicopters used for evacuation of injured soldiers had

\begin{tabular}{|c|c|c|c|c|c|c|c|}
\hline $\begin{array}{l}\text { 5th Century } \\
\text { B.C. }\end{array}$ & 100 A.D. & $\begin{array}{l}\text { Late } 18 \text { th } \\
\text { century }\end{array}$ & $1914-18$ & $1939-45$ & $1950-53$ & $1965-75$ & 1960's \\
\hline $\begin{array}{l}\text { Ancient } \\
\text { Greece } \\
\text { Injured } \\
\text { patients } \\
\text { transported to } \\
\text { specialised } \\
\text { treatment } \\
\text { centres. }\end{array}$ & $\begin{array}{l}\text { Roman Legions } \\
\text { Organise on- } \\
\text { site first aid } \\
\text { stations and } \\
\text { ambulances. }\end{array}$ & $\begin{array}{l}\text { Larrey } \\
\text { (Napoleonic } \\
\text { Army) } \\
\text { Organizes } \\
\text { "flying } \\
\text { ambulance" } \\
\text { and military } \\
\text { hospitals. }\end{array}$ & $\begin{array}{l}\text { WWI } \\
\text { Echelons of } \\
\text { treatment } \\
\text { facilities } \\
\text { improve } \\
\text { care for } \\
\text { injured } \\
\text { soldiers. }\end{array}$ & $\begin{array}{l}\text { WWII } \\
\text { British organize levels } \\
\text { of hospital care. } \\
\text { US army develops } \\
\text { specialized "AUX" } \\
\text { units composed of } \\
\text { specialized teams } \\
\text { which traveled to } \\
\text { front lines. }\end{array}$ & $\begin{array}{l}\text { Korean War } \\
\text { MASH units } \\
\text { enabled } \\
\text { injured } \\
\text { soldiers to } \\
\text { reach } \\
\text { definitive care } \\
\text { within the } \\
\text { "golden hour". }\end{array}$ & $\begin{array}{l}\text { Vietnam War } \\
\text { Helicopter } \\
\text { transport } \\
\text { used } \\
\text { rampantly to } \\
\text { evacuate } \\
\text { injured } \\
\text { soldiers from } \\
\text { front lines. }\end{array}$ & $\begin{array}{l}\text { Excess civilian } \\
\text { mortality } \\
\text { following } \\
\text { trauma } \\
\text { secondary to } \\
\text { inappropriate } \\
\text { care observed } \\
\text { in the US. }\end{array}$ \\
\hline
\end{tabular}


two pods on the outside of the aircraft on either side for evacuation of injured soldiers from the front lines to the awaiting MASH units. The classic pattern of casualty evacuation from previous conflicts was revised in Vietnam. The battalion and regimental aid stations, which had formerly been the first line of surgical care by a physician, were being systematically overflown by the medical evacuation helicopters in Vietnam that were landing in an area where definitive care could be rendered. This area was either a unit from a medical battalion, a mobile surgical hospital, a field hospital, an evacuation hospital, or a hospital ship waiting offshore. These helicopters further decreased time to definitive surgical care to between one and one and a half hours (16).

Pre-hospital time for patients treated at the U.S. Navy Hospital in Da Nang was reported to be only 80 minutes (18). In WWII, it often took four to six months from the time of injury to get an injured soldier back to the United States by hospital ship. Due to improvements in transportation as well as the newly orchestrated evacuation and treatment system, soldiers injured on the battlefields in Vietnam would often arrive at the Naval Hospital, Great Lakes, Illinois within 72 to 96 hours from the time of injury (19). The significant advances in both the systematic care of the injured patient, as well as the improvements in surgical, transfusion-related, and antimicrobial technology resulted in decreases in mortality for patients reaching medical facilities from $8 \%$ in WWI to $4.5 \%$ in WWII to $2.5 \%$ in Korea and to less than $2 \%$ in Vietnam $(20,21,22)$. Average times to definitive care were: 10 hours in WWII, 5 hours in Korea and 1 hour in Vietnam (21).

\section{CIVILIAN TRAUMA CARE SYSTEMS}

The civilian interest and the move towards the regionalisation of trauma care in the United States were secondary to the U.S. military experience with organized trauma care (23). The care of the injured patient evolved and improved significantly in World War II and was further developed during the subsequent Korean and Vietnam wars. It was the Korean and Vietnam conflicts that provided the basis for civilian regionalised emergency medical and trauma systems (21). Civilian trauma providers learned about welltrained paramedical personnel providing care in the field, effective pre-hospital, in-hospital and pre- to inhospital communications, rapid emergency evacuation and transport systems (helicopter evacuations), and specialized "trauma surgeons" working out of specially designed "trauma centers" or MASH units.

In the early 1960s more Americans were killed annually on the nation's highways than were killed during the entire Vietnam conflict (24). In the United States, until the late nineteen-sixties and early nineteenseventies, trauma care mostly occurred in the city and county hospitals or at the hospital nearest to the scene of the accident (25). The hospitals receiving trauma patients were ill-equipped and ill-staffed to handle injured patients and pre-hospital care consisted of poorly trained personnel with little equipment (26). During peak hours and at night these emergency rooms were often staffed with the most junior or unprepared physicians or poorly trained "moonlighters". In the ambulance, there was often only a driver with little emergency training and the patient would be transferred unattended in the back of the ambulance to the nearest hospital. Radios were rarely available in ambulances, and when present they were mainly used to monitor police transmissions in order to try and pick up accident calls and arrive early on-scene. Rockwood recalls that in some cities throughout the US, animals received better emergency care than citizens. They had radio dispatched vehicles and well-trained personnel available for emergency calls for pets. Trauma mortality was often due to late, inadequate or unrecognized
1966

1971

1972

US NRC publishes

"Accidental Death and

Disability" calling for improved, organised trauma care.

US Congress passes "National Highway Safety Act" calling for pre-hospital coordination and communication.

First civilian trauma centres established in San Francisco and Chicago.

\begin{tabular}{|c|c|c|c|c|c|c|}
\hline $\begin{array}{l}\text { Trauma care } \\
\text { system } \\
\text { established } \\
\text { in Illinois. }\end{array}$ & $\begin{array}{l}8 \% \text { decline in } \\
\text { highway } \\
\text { mortality in } \\
\text { Illinois in the } \\
6 \text { months } \\
\text { following } \\
\text { regionalisatio } \\
n \text { of trauma } \\
\text { care. }\end{array}$ & $\begin{array}{l}\text { US Congress } \\
\text { passes } \\
\text { "Emergency } \\
\text { Medical } \\
\text { Services Act" } \\
\text { enabling } \\
\text { regional, } \\
\text { comprehensive } \\
\text { EMS systems. }\end{array}$ & $\begin{array}{l}\text { Levels of } \\
\text { civilian } \\
\text { trauma care } \\
\text { centres } \\
\text { established. }\end{array}$ & $\begin{array}{l}\text { West, Trunkey and } \\
\text { Lim compare } \\
\text { outcome in a } \\
\text { regionalised (San } \\
\text { Francisco County) } \\
\text { compared to a non- } \\
\text { regionalised area } \\
\text { (Orange County) } \\
\text { and find decreased } \\
\text { preventable } \\
\text { mortality in } \\
\text { regionalized area. }\end{array}$ & $\begin{array}{l}\text { ATLS } \\
\text { course } \\
\text { established. }\end{array}$ & $\begin{array}{l}\text { Cales shows } \\
\text { that } \\
\text { preventable } \\
\text { death rate in } \\
\text { Orange } \\
\text { County } \\
\text { decreases } \\
\text { from } 34 \% \text { to } \\
15 \% \\
\text { following } \\
\text { regionalisation } \\
\text { of trauma } \\
\text { care. }\end{array}$ \\
\hline
\end{tabular}


surgical emergencies $(27,28,29)$.

In the early 1960s, a slew of studies were published demonstrating excess mortality following trauma in non-regionalized areas. In 1961, Van Wagoner studied 606 non-combat military deaths and concluded that one sixth (103 cases) of these were secondary to injuries from which recovery could normally be expected and another one sixth from injuries which received inadequate care (96 cases) (30). This was the first published report attempting to assess preventable deaths among injured patients occurring in a non-regionalized system of care. This paper opened the eyes of healthcare providers to the poor and inadequate care that injured patients were receiving and began a movement towards establishing an effective system to prevent these needless deaths.

Following the study by Van Wagoner, Frey showed that out of 159 patients dying as a result of trauma in Michigan, which lacked a regionalized trauma system, 28 received inappropriate care (31). Gertner demonstrated that one third of deaths involving abdominal trauma following motor vehicle collisions in Baltimore, a non-regionalized area, were preventable (32) and Moylan showed that quality of care in hospitals treating trauma patients in five hospitals in Wisconsin was unacceptable in $16 \%$ of seriously injured patients (33). These preventable death studies and other reports observing excess mortality in various areas throughout North America have been vital in the move toward regionalization in respective regions (34).

The realization by the US government of the toll that trauma was taking on society, particularly young society, in terms of morbidity and mortality as well as the "ineffective nonsystems"(20) of trauma care led the National Academy of Sciences to dub injury the "neglected disease of modern society" (35) in the sentinel report of 1966 prepared by the Committee on Shock and Trauma of the National Research Council. This report was titled: "Accidental Death and Disability: The Neglected Disease of Modern Society" and nicknamed the "white paper". Many important and revolutionary recommendations were made which shaped trauma systems as we know them today, including: pre-hospital radio communication systems, categorization of hospitals, the development of trauma registries, implementation of hospital trauma committees, calls for research into clinical areas of trauma care and in the areas of shock and resuscitation, and injury prevention strategies. Following this vital paper, many were convinced that injury was indeed a neglected disease and that it would continue to negatively impact on society if change was not brought about. By the early 1970s, many influential members of medical society believed that lessons learned on the battlefields in Korea and Vietnam in terms of triage, rapid transport of trauma patients to definitive care centers, and standardisation of pre-hospital and inhospital care could be applied effectively to civilian trauma patients (36).

Accidental Death and Disability significantly contributed to what we today consider standard elements of trauma care. It highlighted the importance of standards of care, protocols for pre-hospital care providers, credentialing standards for EMS providers, improvements in accident prevention, emergency first aid and medical care, ambulance services, emergency medical communication, use of air evacuation by helicopter, upgrading emergency departments, improvements and expansion of intensive care units to properly deal with injured patients and specifications for the construction of ambulances. It also called for rapid definitive care of injured patients in the hospital setting and specialized physicians specifically trained and ready at all times to take care of injured patients. This recommendation later was integral in the establishment of a new specialty in medicine Emergency Medicine. A strong case was made for the development of a system of trauma patient care, as well as a system of subsystem components essential to the success of an overall effective effort (20). The document called for the credentialing of four different levels of hospitals to treat trauma patients and suggested that outside credentialing agencies be designated to assign these categories. One of the most important and revolutionary recommendations made in the report was that hospitals and hospital staff be accountable for the outcomes of patients under their care. The creation of trauma registries and outcome analysis, including autopsy studies were therefore born.

Based on the recommendations of Accidental Death and Disability, United States Congress enacted the National Highway Safety Act of 1966. This legislation mandated the Department of Transport to: decrease motor vehicle accident deaths, conduct research into car safety devices, to coordinate pre-hospital care and establish pre-hospital communication.

In 1971, United States Congress proposed a law consisting of program guidelines and technical assistance measures in order to create a nationally coordinated and comprehensive system of regionalized emergency accessibility and care for all American citizens (23). This led to the Emergency Medical Services Act of 1973 (37). The Act enabled the federal government to designate a lead agency role to the Division of Emergency Medical Services in order to develop regional comprehensive emergency medical service (EMS) systems. It also provided financial aid to states for the coordination of EMS activities (38). 
The first civilian trauma units were established in 1966 at Cook County Hospital in Chicago and at San Francisco General Hospital in California $(1,39,40,41)$. The first regionalized trauma system was in established in Illinois in $1971(20,23,42,43,44,45,46,47)$. Lowe and Baker highlighted the concept of the "team approach" to trauma care as being of paramount importance in establishing this system of treating injured patients, which encompassed access to the system through rehabilitation (39). Hospital designation, triage and transport guidelines as well as the concept of a "burn center" were put into place. For the first time, a central bed registry and a patient distribution and triage program were established. In Illinois, there was an eight percent decline in highway mortality in the first 6 months of 1972 (following regionalisation) compared to the same six month period in 1971, prior to regionalisation (47). This decrease in injury related mortality was observed in spite of an increase in highway accidents and injuries during that same period. In 1973, R. Adams Cowley expanded the existing Shock-Trauma program at the University of Maryland to encompass the entire state and established the Maryland Institute for Emergency Medical Services (MIEMS) $(48,49,50)$.

By 1974, only 2 states (Maryland and Illinois) had established emergency medical systems with integrated organized trauma services within these systems. However, in 1974, the trauma system concept took off and slowly, many communities started to organize trauma care. There was however, little civilian outcome data demonstrating a positive effect for systematic trauma care at that time.

In 1973 , Waters reported a $38 \%$ reduction in motor vehicle accident mortality following introduction of a regionalized trauma system in Jacksonville, Florida (51). This was one of the first reports demonstrating a beneficial effect on patient outcome with a systems approach to trauma care. The system included an emphasis on pre-hospital care, well trained pre-hospital crews, rapid response times and improved pre-hospital communication.

In 1976, the American College of Surgeons Committee on Trauma (52) assumed the leadership role in trauma system development with the publication of the first edition of Optimal Hospital Resources for Care of the Seriously Injured $(53,54)$. For the first time in 1977, Detmer et al. defined the four categories of hospitals designated as civilian trauma centres which were to become the basis of today's level I, II, III and IV centers (55). More equipped centers subsequently were shown to have significantly less unacceptable care compared to less equipped, or lower level centers.

\section{WEST AND TRUNKEY REVOLUTIONIZE TRAUMA CARE}

The first and landmark study critically evaluating civilian regionalized care for injured patients and comparing a regionalized to a non-regionalized area was published by West, Trunkey and Lim in 1979 $(56,57)$. This remarkable and original study was responsible for a new field of healthcare and health services research. They retrospectively studied one hundred consecutive motor vehicle fatalities in two counties (San Francisco and Orange County) in California between 1974 and 1975. The injured patients in San Francisco County were taken to a single trauma centre and the patients in Orange County were transported to the closest receiving hospital (39 hospitals receiving injured patients). They excluded patients who were transferred from other facilities where they had received care prior to treatment in the study hospitals and patients who died prior to reaching hospital. Deaths were classified as clearly preventable, potentially preventable and not preventable by an expert panel.

Patients in Orange County were significantly younger and had injuries of lower severity than patients in the San Francisco County cohort. Nevertheless, a panel of experts deemed that thirty-seven percent (11/30) of nonCNS related deaths in the Orange County cohort were judged to be clearly preventable compared to none in the San Francisco County cohort. Another 37\% (11/30) of deaths in Orange County were judged to be potentially preventable, compared to only one death in San Francisco. This study was the first to begin to shed light on the importance of specialized, early definitive care of trauma patients and the magnitude of bringing injured patients directly to appropriately staffed, experienced and equipped care facilities.

Orange County was regionalized in 1980. Following the study by West, a complementary autopsy study $(58,59)$ was performed on patients injured in motor vehicle collisions in Orange County before and after trauma care regionalisation $(60,61,62)$. Cales retrospectively evaluated the outcomes of patients following implementation of a regionalized trauma system in Orange County by reviewing trauma deaths via an expert panel. This was the first ever before and after study of regionalized trauma care and served as a standard to which numerous subsequent studies would be compared. Fifty-eight deaths occurring prior to regionalisation were compared to 60 deaths occurring following implementation of a trauma system. Potentially preventable death rates dropped from $34 \%$ prior to regionalisation to $15 \%$ following regionalisation $(\mathrm{p}<0.02)$. Fifty-four percent of potentially preventable deaths occurred in patients 
transported to non-trauma centres, compared to $4 \%$ of patients transported to trauma centres. They also found that the death rate from vehicular trauma dropped from 15.7 per 100,000 to 13.9 per $100,000(\mathrm{p}<0.03)$ in the first year following regionalisation and from 15.8 per 100,000 to 12.4 per 100,000 after 2 years of regionalisation $(\mathrm{p}<0.02)$. These remarkable and convincing results were strengthened due to the fact that the patients in the post-regionalisation cohort had higher Injury Severity Scores (ISS) and median age compared to those in the pre-regionalisation cohort. The improvement in outcomes was in part attributed to the aggressive approach to the care of the traumatized patient following regionalisation, which was suggested by an increased percentage of patients who received surgical interventions (62). Even though there has been some debate over the statistical methods (i.e. preventable death rate analysis) used to demonstrate efficacy in the early studies of trauma systems $(63,64,65,66,67,68,69)$, these results are not only impressive, they also are responsible for the changes in trauma care occurring over the following 30 years.

The studies out of Orange County disclosed to the public, for the first time, the problem of inadequate trauma patient care due to the absence of a system. Backed by public demand, governments and healthcare authorities were forced to be accountable for trauma outcomes to the public. The scientific evaluation of trauma systems and their impact on society by West and Trunkey from the 1970s are unparalleled in terms of both their originality and impact on trauma care systems. These studies are the basis of modern systematic trauma care as we know and take for granted today.

\section{ADVANCED TRAUMA LIFE SUPPORT}

Prior to 1980, there were no standardized protocols or programs to train physicians in the appropriate care of the injured patient. In 1976, an orthopedic surgeon from Nebraska initiated the Advanced Trauma Life Support (ATLS) Course for training physicians in trauma care, after his wife and 3 children were killed when he crashed his plane (70). The care that his injured wife and children received was poor and this motivated the surgeon to create a course in order to train physicians with little chance to practice trauma treatment skills in the acute management of injured patients. This course was revised and adopted by the American college of Surgeons Committee on Trauma in 1979. It has since become an international standardized trauma training program, further contributing to the standardization of trauma care across regions.

\section{MODERN DAY TRAUMA SYSTEMS}

In 1985 and 1988, the Committee on Trauma
Research of the National Research Council and the Institute of Medicine published "Injury in America, A Continuing Public Health Problem" (71) and "Injury Control, A Review of the Status and Progress of the Injury Control, Program at the Centers for Disease Control" (72). These reports were a followup to the white paper and looked at the progress that had been achieved since 1966 in trauma treatment and prevention and made extensive recommendations regarding the future of trauma care and trauma systems. These recommendations were based on the extensive body of scientific evidence that had surfaced since 1966 regarding trauma system effectiveness. The committee stated that trauma was a public health problem whose toll was unacceptable. They called for the nation to address the problem through research and legislation. The challenge proposed in Injury in America was to establish injury prevention and treatment as a recognized interdisciplinary field of scientific evaluation and ongoing research. The 1985 report was again expanded on and reassessed in 1999 in the report put out by the Institute of Medicine; "Reducing the Burden of Injury - Advancing Prevention and Treatment" (73). This report reemphasized the point that had been highlighted previously in Accidental Death and Disability, Injury in America and Injury Control: investment in injury research in the United States did not balance the magnitude of the problem of injury. It further emphasized the positive impact of systems of trauma care on the outcome of injured patients and called for the development of more trauma systems throughout the country.

Trauma systems and regionalized trauma care has seen multiple changes and improvements over the years. It is the authors' opinion that future challenges for trauma systems include the identification of specific components of trauma systems and their impact on outcome, the creation of effective tailormade and cost-effective systems created to fit individual community needs, the creation of novel methods to assess population-based outcome following trauma, as well as the extension of the excellent results demonstrated in urban areas to the rural setting. The advent of telemedicine promises to improve trauma care in these rural and often inaccessible areas, however further research in this area is required $(74,75,76)$. Furthermore, aircraft (helicopter and fixed wing) are being used to transfer critically injured patients from rural centres to urban tertiary trauma centres, improving systematic care and outcomes for patients injured at great distances from definitive care facilities. 


\section{REFERENCES}

1. Trunkey DD. History and development of trauma care in the United States. Clinical Orthopaedics and Related Research 2000;374:36-46.

2. Homer. The Iliad. Translated by Robert Fagles New York: Penguin Books Ltd., 1990.

3. Eastman AB. Blood in our streets. The status and evolution of trauma care systems. Arch Surg 1992;127:677-681.

4. Trunkey DD. Trauma care systems. Emerg Med Clin N Am 1984;2:913-922.

5. Calne Sir Roy. The Illustrated Hsitory of Surgery. Calne Sir Roy. Second ed. Barbican, London: Harolde Starke Publishers Ltd, 2000.

6. Davis JH, Pruitt JH, and Pruitt BA. History. Chapter 1. History. Mattox KL, Deliciano DV, and Moore EE. Fourth Edition ed. New York: McGraw-Hill Companies Inc., 2000.

7. Woodward JJ. The Medical and Surgical History of the War of the Rebellion. Washington, DC: Government Printing Office, 1875.

8. Mullins RJ. A historical perspective of trauma system development in the United States. J Trauma 1999;47:S8-S14.

9. Bailey H. Surgery of Modern Warfare. Chapter LXXX. Surgery of Modern Warfare. Second Edition ed. Baltimore, Maryland: The Williams and Wilkins Company, 1942.

10. Beebe GW and DeBakey ME. Battle Casualties. Springfiel, Illinois: Charles C Thomas, 1952.

11. Trueta J. Principles and Practice of War Surgery. First Edition ed. St. Louis: C.V. Mosby Company, 1943.

12. Trunkey DD. Trauma. Scientific American 1983;249:28-35.

13. Trunkey DD. Overview of trauma. Surg Clin N Am 1982;62:3-7.

14. United States Department of Defense. Emergency War Surgery NATO Handbook. Frank B Berry (Assistant Secretary of Defense, Health and Medical Washington, D.C.: United States Government Printing Office, 1958.

15. Champion HR. Trauma centers in the USA - past and present. $\mathrm{Br}$ J Surg 1999;86:721-722.

16. Eiseman B. Combat casualty management in Vietnam. J Trauma 1967;7:53-63.

17. Byerly WG and Pendse PD. War surgery in a forward surgical hospital in Vietnam: A continuing report. Military Medicine 1971;136:221-226.

18. Cloutier CT, Lowery BD, and Carey LC. The effect of hemodilutional resuscitation on serum protein levels in human hemorrhagic shock. J Trauma 1969;9:514.

19. Haacker LP. Time and its effects on casualties in World War II and Vietnam. Arch Surg 1969;98:39-40.

20. Boyd DR, Pizzano WA, Romano TL, Stiegmann GV, and Nyhus LM. Regionalization of trauma patient care: the Illinois experience. Surg Annu 1975;7:25-52.

21. Heaton LD. Army medical service activities in Viet Nam. Military Medicine 1966;131:646-647.

22. Barnes A Jr. Progree report: The blood program in Vietnam. Military Medicine 1970;135:1-7.

23. Boyd DR and Cowley RA. Comprehensive regional trauma/emergency medical services (EMS) delivery systems. World J Surg 1983;7:149-157.

24. Shackford SR. The evolution of modern trauma care. Surg Clin N Am 1995;75:147-156.

25. Blaisdell FW. The pre-Medicale role of city/county hospitals in education and health care. J Trauma 1992;32:217-228.

26. Rockwood CA Jr., Mann CM, Farrington JD, Hampton OP, and Motley RE. History of emergency medical services in the United States. J Trauma 1976;16:299-308.

27. Root GT and Christensen BH. Early surgical treatment of abdominal injuries. Surg Gynec Obstet 1957;105:264-267.

28. Perry JF and McClellan RJ. Autopsy findings in 127 patients following fatal trahhic accidents. Surg Gynec Obstet 1964;119:586-590.

29. Fitts WT, Lehr HB, Bitner RL, and Spelman JW. An analysis of 950 fatal injuries. Surgery 1964;56:663-668.

30. Van Wagoner FH. Died in hospital: a three year study of deaths following trauma. J Trauma 1961;1:401-408.

31. Frey CF, Huelke DF, and Gikas PW. Resuscitation and survival in motor vehicle accidents. J Trauma 1969;9:292-310.

32. Gertner HR Jr., Baker SP, Rutherford RB, and Spitz WU. Evaluation of the management of vehicular fatalities secondary to abdominal injury. J Trauma 1972;12:425-431.

33. Moylan JA, Detmer DE, Rose J, and Schulz R. Evaluation of the quality of hospital care for major trauma. J Trauma 1976;16:517-523.

34. Bazzoli GJ. Community-based trauma system development: key barriers and facilitating factors. J Trauma 1999;47:S22-S24.

35. National Academy of Sciences. Accidental Death and Disability: The Neglected Disease of Modern Society. Washington, DC: National Academy of Sciences / National Research Council, 1966.

36. Hackey RB. The politics of trauma system development. J Trauma 1995;39:1045-1053.

37. Law of the 93rd congress emergency medical services act of 1973. Bill/Resolution Number: Public Law 93-155. Washington DC. 11-16-1973.

38. Moore EE. Trauma sysrems, trauma centers, and trauma surgeons - Opportunity in managed competition. J Trauma 1995;39:1-11.

39. Lowe RJ and Baker RJ. Organization and function of trauma care units. J Trauma 1973;13:285-290.

40. Freeark RJ. 1982 AAST presidential address: the trauma center: its hospitals, head injuries, and heroes. J Trauma 1983;23:173178.

41. Trunkey DD and Eastman AB. Development of Trauma Systems. Chapter 1. Development of Trauma Systems. Trunkey DD and Lewis FR. Fourth Edition ed. St. Louis, Missouri: Mosby, 1999.

42. Boyd DR. A symposium on the Illinios trauma program: a systems approach to the care of the critically injured. J Trauma 1973;13:275-276.

43. Goldberg J, Levy PS, Gelfand HM, Mullner R, Iverson N, Lemeshow S, and Rothrock J. Factors affecting trauma center utilization in Illinois. Med Care 1981;19:547-565.

44. Boyd DR, Dunea MM, and Flashner BA. The Illinois plan for a statewide system of trauma centers. J Trauma 1973;13:24-31.

45. Metzmaker CO and Folse R. A trauma center in a nonmetropolitan community. J Trauma 1973;13:291-295.

46. Boyd DR. A symposium on the Illinois trauma program: a systems approach to the care of the critically injured. J Trauma 1973;13:275-276.

47. Boyd DR, Mains KD, and Flashner BA. A systems approach to statewide emergency medical care. J Trauma 1973;13:276-284.

48. Cowley RA. Trauma center. A new concept for the delivery of critical care. J Med Soc NJ 1977;74:979-987.

49. West JG, Williams MJ, Trunkey DD, and Wolferth CC. Trauma systems. Current status - future challenges. JAMA 1988;259:3597-3600.

50. Cowley RA and Scanlan E. University trauma center: Operation, design and staffing. Am Surg 1979;45:85.

51. Waters JM and Wells CH. The effects of a modern emergency medical care system in reducing automoblile crash deaths. J Trauma 1973;13:645-647.

52. Hampton OP. The Committee on Trauma of the American College of Surgeons 1922-1972. Bull Am Coll Surg 1972;57:7-13.

53. Committee on Trauma - American College of Surgeons. Optimal hospital resources for care of the seriously injured patient. $61 \mathrm{ed}$. 1976. 
54. Optimal hospital ressources for care of the seriously injured. Bull Am Coll Surg 1976;61:15-22.

55. Detmer DE, Moylan JA, Rose J, Schulz R, Wallace R, and Daly R. Regional categorization and quality of care in major trauma. J Trauma 1997;17:592-599.

56. West JG, Trunkey DD, and Lim RC. Systems of trauma care. Arch Surg 1979;114:455-460.

57. West JG, Trunkey DD, and Lim RC. The Classic - Systems of trauma care. A study of two counties. Clinical Orthopaedics and Related Research 1995;318:4-10.

58. West JG. An autopsy method for evaluating trauma care. J Trauma 1981;21:32-34.

59. West JG. Validation of autopsy method for evaluating trauma care. Arch Surg 1982;117:1033-1035.

60. Cales RH. Trauma mortality in Orange County: the effect of implementation of a regional trauma system. Ann Emerg Med 1984;13:1-10.

61. Cales RH, Anderson PG, and Heilig RW. Utilization of medical care in Orange County: the effect of implementation of a regional trauma system. Ann Emerg Med 1985;14:853-858.

62. West JG, Cales $\mathrm{RH}$, and Gazzaniga $\mathrm{AB}$. Impact of regionalization. The Orange County experience. Arch Surg 1983;118:740-744

63. MacKenzie EJ, Steinwachs DM, Bone LR, Floccare DJ, Ramzy $\mathrm{AI}$, and The preventable death study group. Inter-rater reliability of perventable death judgments. J Trauma 1992;33:292-303.

64. Salmi LR, Williams JI, and Waxweiler RJ. Measuring the impact of trauma care on survival: rates of perventable death, effectiveness, and efficacy. J Clin Epidemiol 1990;43:399-403.

65. Mendeloff JM and Cayten CG. Trauma systems and public policy. Ann Rev Publ Health 1991;12:402.

66. Wesson DE, Williams JI, Salmi LR, Spence LJ, Armstrong PF, and Filler RM. Evaluating a pediatric trauma program: effectiveness versus preventable death rate. J Trauma 1988;28:1226-1231.
67. Roy PD. The value of trauma centres: a methodologic review CJS 1987;30:17-22.

68. Clark RB. Trauma centers and the New Evangelists. Ann Emerg Med 1981;10:545-546.

69. Clark DE. Comparing institutional trauma survival to a standard: Current limitations and suggested alternatives. J Trauma 1999;47:S92-S98.

70. American College of Surgeons. Advanced Trauma Life Support for Doctors (ATLS). Sixth Edition ed. Chicago, IL: American College of Surgeons, 1997.

71. National Research Council and the Institutes of medicine, Committee on Trauma Research. Injury in America. A Continuing Public Health Problem. Foege WH Washington, D.C: National Academy Press, 1985.

72. National Research Council and the Institutes of medicine, Committee on Trauma Research. Injury Control, A Review of the Status and Progress of the Injury Control, Program at the Centers for Disease Control. Washington, D.C.: National Academy Press, 1988.

73. Institute of Medicine - Committee on Injury Prevention and Control, Division of Health Promotion and Disease Prevention. Reducing the Burden of Injury - Advancing Prevention and Treatment. Bonnie RJ, Fulco CE, and Liverman CT Washington, D.C.: National Academy Press, 1999.

74. Aucar J, Granchi T, Liscum K, Wall M, and Mattox K. Is regionalization of trauma care using telemedicine feasible and desirable? Am J Surg 2000;180:535-539.

75. Lambrecht CJ. Telemedicine in trauma care: description of 100 trauma teleconsults. Telemed J 1997;3:265-268.

76. Rogers FB, Ricci M, Caputo M, Sartorelli K, Callas P, and et al. The use of telemedicine for real-time video consultation between trauma center and community hospital in rural setting improves early trauma care: preliminary results. J Trauma 2001;51:1037-1041.

Moishe Liberman MD, is a fourth year resident in the Division of General Surgery at McGill University. He is also a research fellow in the Department of Experimental Surgery at McGill.

David S. Mulder MD, MSc, FRCSC is the Chairman of the Division of Cardiothoracic Surgery at the McGill University Health Center, Senior Surgeon at the Montreal General Hospital, and Professor of Surgery at McGill University.

John S. Sampalis PhD, is the Head of Surgical Epidemiology at McGill University, an Associate Professor in the Departments of Surgery, Epidemiology and Biostatistics, and an Associate Professor in the Department of Social and Preventive Medicine at Université de Montréal and at Université de Laval. He has been a past recipient of the Medical Research of Canada Scientist award and is currently a senior scientist supported by the Fonds de la recherche en sante du Quebec (FRSQ). 